\title{
ÖNKORMÁNYZATI PERSPEKTÍVÁK TÖRTÉNELMI TÁVLATBÓL
} Kajtár István (1992) Magyar városi önkormányzatok (1848-1918), Területi és települési kutatások 9. Akadémiai Kiadó, Budapest

Kajtár István bízvást adhatta volna munkåjának a szaktörténészi, a szakmai követelmények miatt távolságtartó hưvös könyvcíme [Magyar városi önkormányzatok (1848-1918)] helyett a recenzió piacibb, és valljuk be, reklámízúbb címét. Azonban míg a szerzốt címválasztásban is köti a szakmai tárgyilagosság követelménye, hiszen ez a kơnyv a magyar polgári városi önkormányzat monográfiáját kívánta sine ira et studio a vizsgált idôszakban megírni, addig a recenzesnek megvan az az alkotói szabadsága, hogy más szempontból más szemüvegen keresztül olvassa és méltassa, vagy éppen kritizálja a müvet.

Tudományosabb igényú munkák minốsítésének egyik szempontja azok idốszerûsége. Ebbốl a szempontból e könyv kétségkívül idốszerû, hiszen az önkormányzatok múködését valamennyien csak most tanuljuk. Kajtár Istvấn külön érdeme, hogy a téma feldolgozását akkor kezdte meg, amikor önkormányzatokrốl a magyar közigazgatásban még szó sem lehetett. Ugy tưnik, tehát kutatni nemcsak azt kell, ami éppen piacképes az adott pillanatban. A tudományos munkával szemben támasztott másik, szigorúbb kritérium a gyakorlati felhasználhatóság. Azonban bármilyen meglepô, ez a történeti munka, ebból a szempontból is kiállja a próbát. A szerzó ugyanis a jogintézményeket társadalmi összefüggéseikbe ágyazza bele, kimutatva, hogy egy bizonyos megoldáshoz milyen történelmitársadalmi-politikai feltételek mellett jutottak el, és ez a módszer, párosulva az összehasonlí- tó elemzéssel, alapot ad a mára is érvényes tanulságok leszưrésére.

Minden egyes monográfiának természetesen nagyon sok rétege van, amelyek különféle szakmai szempontokból fontosak lehetnek, jelen recenzió azonban arra az egy szempontra koncentrál, hogy mi az, amit az önkormányzatok szakemberei és a téma iránt érdeklốdốk felhasználhatnak a jelenlegi viszonyok alakításában, illetve a jelenlegi viszonyok megértésében.

Az elổzố bekezdésben említett, a jogintézmények leírásán túlmutató szemlélet jelenik meg az elsố fejezetben. Ebben rövid áttekintést kapunk az európai burzsoá önkormányzati jog alakulásáról. A modern városi jogok különbözố nemzeti - angol, francia, porosz, osztrák - modelljeit egyrészrôl a középkori városi jogi tradíciók, másrészt a központi hatalomnak a jogalkotást centralizáló lépései, valamint az adott konkrét politikai feltételek hatására alakulnak ki. Az európai háttér felvázolásával a magyar megoldási kísérletek elhelyezhetôk a korabeli törekvések között, továbbá áttekinthetổvé válnak az alsótábla, a felsôtábla és a kormányzat küzdelmei. A különbözố politikai áramlatok hatásának bemutatása, a törvénytervezeteket megfogalmazó küldöttek egész Európát átfogó tájékozottsága mindenesetre érdekes adalék, hiszen nagyon elterjedt nézet az, hogy a polgári eszmék beáramlása Magyarországra a XIX. század második felében, vagy még késốbb történt.

A következố, III-IV. fejezetekben tekinti át Kajtár István az önkormányzatokra vonatkozó 
jogi szabályozást. Azt mondhatjuk, hogy jogtörténésztôl meglepô, hogy a jogintézmények vizsgálatának viszonylag kevés, négy-öt fejezetet szentel. Úgy tû́nik, a szerzốt a tényektổ, a tényleges mû́ködéstôl elválasztott tételes jogi szabályozás önmagában való szépsége és összefüggései kevésbé érdeklik, mint a jogszabályok tényleges múködése. E történeti jellegú fejtegetések során mutat rá a szerzô a korabeli szabályozás hiányosságaira. A korabeli jogi szabályozás krízisének több oka van. Egyrészt a válságnak van közjogi vetülete, ami abban foglalható össze, hogy a városok igényeltek volna egy külön városi törvényt, amely nem a megyékkel együtt kezeli ôket. $A$ városi törekvések azonban különbözố okok miatt zátonyra futottak. A városok merev felosztása azonban a szerzô által kidolgozott urbanisztikai mérôszámok alapján is indokolatlannak tủnik. Helyesen emeli ki azonban Kajtár István azt, hogy a konfliktus inkább közjogi jellegú, hiszen figyelembe véve a korabeli városi kommunális igények korlátozott voltát, legalábbis Budapest kivételével, a klasszikus hatósági jellegû́ városi jog képes volt a városigazgatás feladatait ellátni. Azaz úgy tûnik, ebbốl a szempontból a korabeli szabályozás adekvát volt a társadalmi viszonyokkal.

Bár a könyv fentebb ismertetett részei is tanulságosak, a városi önkormányzatok szabályrendeleti jogával, a városok szervezeti kereteivel, a városok rendôrségével foglalkozó fejezetek a gyakorlati problémákkal gyürkôzổ várospolitikusok, jogászok, szervezési szakemberek számára különösen érdekesek lehetnek. A városok szabályrendeleteinek szisztematikus feldolgozásával, elemzésével a történeti jogtudomány mind a mai napig adós, ezért Kajtár István munkája, amely több város szabályrendeleteit tekinti át, úttörố jellegú. Ezidáig csak a szabályrendeletek országos szabályozásáról rendelkeztünk ismeretekkel, e könyvnek köszönhetóen azonban a jog ,"mikrofolyamataiba" is betekintést nyerhetünk.

Mivel az önkormányzatiságot valamennyien most tanuljuk, a gyakorlati élet számára fontos a múltbeli tapasztalatok megismerése, és mivel ez a gyakorlat nem folyamatos, hanem megszakított, célszerú az ezt feldolgozó irodalomra támaszkodni. Ebbốl a szempontból különösen fontosak azok a részek, ahol a szerzố az önkormányzatok szabályrendeleteinek szabályozási tárgyait csoportosítja, (vagy) Pécs város szabály rendeleti joglakotási eljárását ismerteti, vagy éppen a városi rendổség és a városi rendészet megszervezésérôl szól. Nem lebecsülhetổ jelentôségû́ egy város életében a közgyúlés munkájának megszervezése, az interpellációs gyakorlat kialakítása. Mindezek vonatkozásában az olvasó részletes adatokat és bizonyos alapvetô összefüggéseket találhat a vonatkozó fejezetekben. Ezen történeti tények és összefüggések ismerete hasznos igazságokat, ötleteket adhatnak azoknak, akik éppen a városi igazgatás problémáival küszködnek.

Míg a fentiek a városi igazgatás jogi ,,technikai" ismereteit bốvítik és ezen technikai ismeretek a városok életének minden rendszerben, minden körülmények között részeit képezik, addig az önkormányzatok vezetóinek személyi összetétele politikai pikantériával is bír. A szerzố több városra terjedốen vizsgálja a vezetổ tisztségviselők és a tanácsnokok kontinuitását. A vizsgált idốszakban a mindenkori hatalommal szemben az együttmủködési készség tartósnak bizonyult, a városi vezetôk mindvégig nagyfokú , alkalmazkodási" képességról tettek tanúbizonyságot. Mindez persze interpretálható úgy is, hogy a városi vezetôk megalkuvóbbak, de úgy is, hogy a , városi adminisztráció vezetése bizonyos mértékig »érzéketlen « a nagypolitikai változások iránt." Ez a megfigyelés természe- 
tesen a megyei igazgatással összefüggésben igaz, hiszen a megyéknél a kontinuitás jóval alacsonyabb.

A másik érdekes tény, amelyre a vezetố tisztviselốk pályafutásának elemzése során bukkan a szerzó az, hogy a polgármesteri pozíciót betöltốk pályafutása nagyon sajnálatosan alakul. A polgármesteri pozícióba aránylag idôsebb korban, hosszabb városigazgatási tapasztalat után juthatott valaki, míg a megyékben gyorsabb közigazgatási karrierre lehetett számítani. Bár a polgármesteri jövedelem az adott korban elég tekintélyesnek számított és a presztízse is elég magas volt, az esetek döntő többségében az országos politikai karrier lehetốsége a képviselóházi tagságnál véget ért. Ez a gyakorlat eltér az amerikai, vagy éppen a Kajtár István által példaként említett német gyakorlattól.

A könyv utolsó fejezete a városi önkormányzatok vagyoni helyzetét tekinti át részletes, valamennyi városunkat átfogó táblázattal. Sajnálatos, hogy valószínúleg a könyv szerkesztési szempontjai miatt a roppnat érdekes és tanulságos fejezet ilyen rövid maradt, különös tekintettel arra, hogy a szerzőnek a könyvben feldolgozott adatokon túl is vannak ismeretei a korabeli városgazdálkodás helyzetérổ.

E hiányosságtól eltekintve azonban az önkormányzati múlttal megismerkedni kívánók, valamint azok, akik ötleteket keresnek problémáik megoldására, ezt a könyvet nagy haszonnal forgathatják.

Maczonkai Mihály

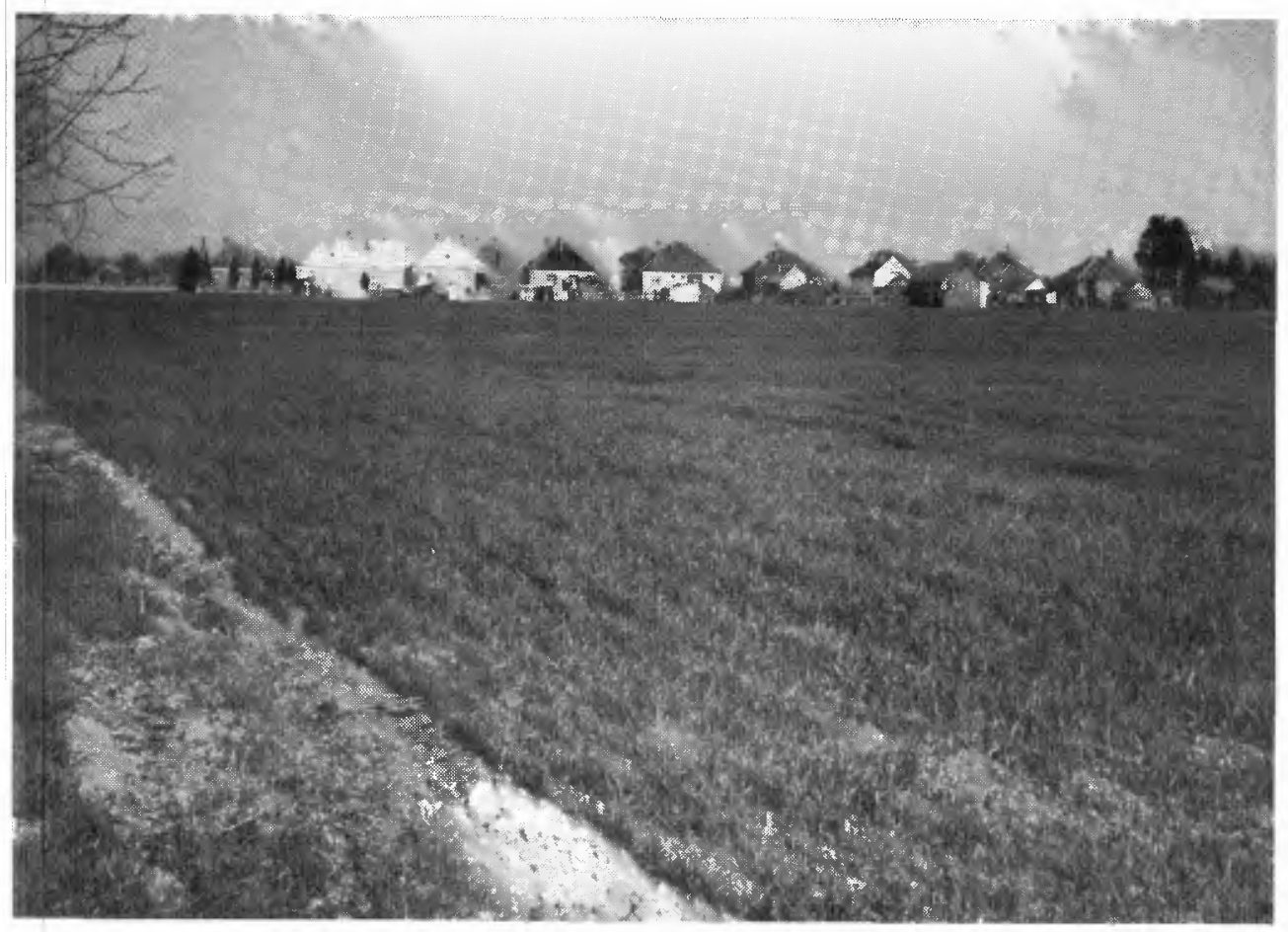



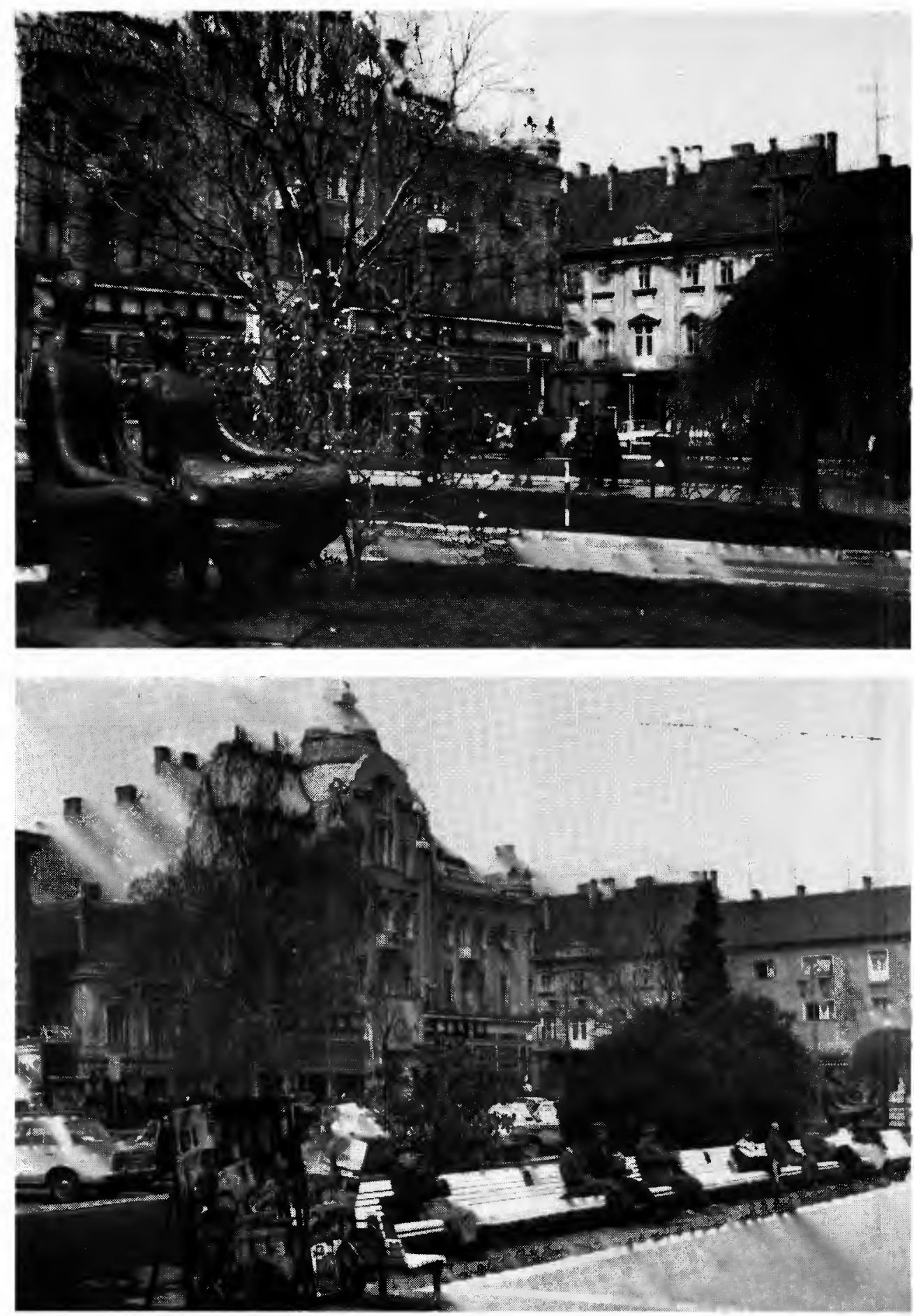